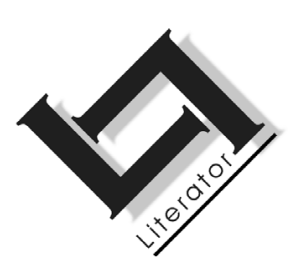

\title{
Animals and nature: mapping storylines and metaphors in David Kramer's narratives $^{1}$
}

\author{
M. Slabbert \\ Department of English \\ University of Stellenbosch \\ STELLENBOSCH \\ E-mail: mslabbert@sun.ac.za
}

\section{Abstract \\ Animals and nature: mapping storylines and metaphors in David Kramer's narratives}

This article discusses the representation of animals and nature in selected lyrics from the oeuvre of singer, songwriter and producer David Kramer and considers his engagement with historical and contemporary discourses about human-animal and human-nature interaction in relation to ecological awareness within a South African context. I trace the socio-political commentary voiced through his depiction of animals in the folksongs he wrote during apartheid, especially in lyrics from the album "Baboondogs" (Kramer, 1986). Kramer also employs intertextual references to traditional South African folksongs and tales in his music. Furthermore, the social and environmental significance of Kramer's representations of nature in a selection of his postapartheid lyrics is investigated. I argue that the pedagogical value of Kramer's cultural commentary can

1 This article developed partly from my research for a scholarly biography on the life and work of David Kramer, written in collaboration with Dawid de Villiers, and forms part of my NRF post-doctoral research project. Whereas, in this article, I take a more literary-critical approach in working with Kramer's lyrics as narratives, David Kramer: a biography (2011) approaches his music in a more holistic way. I consequently also refer to the speaking/singing voice in these narratives as either speaker or narrator depending on the content. Please note that the Afrikaans lyrics are paraphrased in English and not accurately translated. 
contribute significantly to the challenge of teaching animal studies and ecocriticism in South African context.

\section{Opsomming}

\section{Diere en natuur: storievertelling en metafore in David Kramer se narratiewe}

In hierdie artikel word die uitbeelding van diere en die natuur in gekose lirieke uit die oeuvre van liedjieskrywer, sanger en regisseur David Kramer ondersoek. Sy gemoeidheid met historiese en kontemporêre diskoerse oor mens-dierinteraksie en mens-natuurinteraksie, asook sy ekologiese bewustheid in 'n Suid-Afrikaanse konteks, sal oorweeg word. Kramer se sosiopolitieke kommentaar, met spesifieke verwysing na die dier-en natuuruitbeeldings in sy volksliedjies wat tydens apartheid geskryf is en veral in die album "Baboondogs" (Kramer, 1986) figureer, sal in hierdie analise aangetoon word. Kramer gebruik ook intertekstuele verwysings uit tradisionele Suid-Afrikaanse volksliedjies en verhale in sy musiek. Die maatskaplike en omgewingsimplikasies van Kramer se natuuruitbeeldings in 'n seleksie van sy postapartheid lirieke sal eweneens ondersoek word. Die gevolgtrekking is dat die pedagogiese waarde van Kramer se kulturele kommentaar uiteindelik 'n noemenswaardige bydrae kan lewer tot die onderrig van dierestudie en ekokritiek in 'n Suid-Afrikaanse konteks.

\section{Introduction}

In recent years, a growing consciousness about the global ecological crisis has stimulated dialogue and debate in the media and across academic disciplines, as the lively critical discussions in animal studies and ecocriticism illustrate. The historical and cultural significance of representations of animals and nature 2 in artistic works from the past and the present, has become a source for

2 The scope of this essay does not allow me to discuss the complexities of the debates about the term animal in animal studies. However, I rely on Woodward's explanation of the term human and nonhuman animal. She describes "Human-animal studies" as aiming to "decentr[e] [...] the human subject in relation to animals" (Woodward, 2008:6). I acknowledge the historical shifts in views and definitions of nature (external and internal) and the complex, ongoing debates about the "Idea of Nature" as discussed by theorist Leo Marx (2008:8), whose definition I apply in my argument. Marx broadly describes nature as a "topographical and biophysical" space or landscape (Marx, 2008:17-18). Also see Curry's (2008:52-54) views on "Nature Post-Nature" and the work of socioenvironmentalists such as Dickens in Society and nature: changing our environment, changing ourselves (2004), Hay in Main currents in Western environmental thought (2002) and Hannigan in Environmental sociology (1995). 
reflection on, and analysis of the role artistic productions play, not only in illustrating shifting perspectives on human-nature interaction, but in creating proactive awareness. Slovic (2008:137) argues in Going away to think that

... we need literature - or art more generally - to help us use our senses more fully and intensely. We need to overcome the abstractness of our ecological awareness and learn to live through such awareness, to feel our presence in the world.

Slovic (2008:137) defines this state of awareness as "the realm of sensory ecology - an appreciation of our own presence in the physical world and our connections with other beings". This article analyses representations of animals and nature in selected lyrics from the oeuvre of South African singer, songwriter and producer, David Kramer, to illustrate his, at times critical, engagement with historical and contemporary discourses about human-animal and human-nature interactions and ecological awareness in a South African context. In the first part of the article, Kramer's socio-political commentary through his depictions of animals in folksongs written during apartheid is been considered, by focusing on the figures of the baboon and, to a lesser extent, the dog as metaphors or analogies captured by the title of his one album Baboondogs (Kramer, 1986). Kramer's intertextual use of elements from traditional South African folksongs and tales is central to the argument. In the second part of the article, the social and environmental significance of Kramer's representations of nature and animals in a selection of his postapartheid lyrics is investigated, most notably the recordings on Huistoe (Homewards; Kramer, 2004), some of which also feature in the musical production Die ballade van Koos Sas (The ballad of Koos Sas; Kramer, 2001; 2008), and Hemel \& aarde (Heaven \& earth; Kramer, 2007). Through this process I hope to reflect on the cultural and pedagogical significance of Kramer's stories in creating ecological awareness in teaching ecocriticism in a South African context.

Kramer became famous after the launch of his first album, Bakgat!, in 1981. He has since released fourteen albums and produced ten musicals of which seven were in collaboration with Taliep Petersen. 3

3 Productions such as District Six - the musical (1986) brought the Kramer/ Petersen collaboration international fame. Kat and the kings (1995) received the Laurence Olivier Award for best new musical in 1997 in London while the Broadway production was nominated for three Drama Desk Awards and a Drama League Award in 1999. 
Kramer remains first and foremost a storyteller who draws on South African folktales, songs and oral traditions to explore socio-political issues such as racism, discrimination, exploitation and feelings of dislocation and displacement reflective of a complex heterogeneous society. He is primarily concerned with the rich cultural framework and the topology of the Cape, the Karoo and the Northern-Cape, as well as the influence of "coloured" heritage on South African and Afrikaans language and culture. 4 De Villiers traces the significance of place, space and a sense of being in his examination of Die ballade van Koos Sas (Kramer, 2001), the first Afrikaans musical to be staged in the Tricycle Theatre in London in July 2009 (with electronic surtitles), and he notes that Kramer's "work reconstructs a shared and heterogeneous folk tradition, in which the very topological features of the land play a constitutive role" (De Villiers, 2010:60).

\section{Style and language}

Kramer, in a discussion with Julian Roup in 2004, explained that "the most political thing [he] did in [his] work was not the content but the form". He pointed out that although "[p]olitical messages are sought in the content [...] the really radical stuff was in the style and the form" (Roup, 2004:161). Language, coupled with storytelling, remains one of Kramer's interests and Cape vernacular expression forms a significant aspect of his work. Although Kramer's oeuvre contains a mixture of Afrikaans and English, he consciously decided at the outset of his musical career to express himself in Afrikaans, as he explained to Roup (2004:161):

I asked myself, was there a South African folk-music culture? [...] The only folk music 5 that I could think of was the stuff I grew up with - Suikerbossie and Bobbejaan klim die berg. Simple Afrikaans songs that were sung around campfires.

But when I started looking more closely at this Afrikaans folk music in the 70s it was a revelation to me [...] I realised that this has not been written by white people. [...]

So it was completely liberating for me, understanding the roots of Afrikaans, and that is when I started writing Afrikaans songs.

4 See De Villiers's (2010:58-68) study of Die ballade van Koos Sas.

5 The inconsistency between the spelling of folk-music and folk music in this quotation appears in the original text. 
The thing for me was to make a connection to the folk tradition so that there would be some reason to move into the future, to reconnect with an Afrikaans folk tradition ...

He added that, "[i]n the 80s, opposition politicos encouraged people to stop speaking Afrikaans, just at a time when I was rediscovering Afrikaans" (Roup, 2004:163). Given this background, it is significant that his eighth album, Baboondogs (Kramer, 1986), is his first predominantly English album. English, the language of the coloniser, but also of the transnational, becomes the medium of protest. This represents Kramer's return to English as language of critique as well as his stylistic rebellion against conservative white Afrikaner ideology. Kramer, in an interview, argued that since "the country was burning" he could no longer continue performing to mainly white Afrikaner audiences who often functioned in complete disregard of the political situation in the country. 6

The musical arrangement on Baboondogs differs significantly from his preceding productions. It is recorded in the contemporary style of the 1980s, rather than in the style that was to become his trademark: a fusion of local folk music traditions, i.e. boeremusiek, Cape moppies and kwela. With this stylistic change Kramer aimed to reach an English-speaking and potentially politically conscious audience with whom he could engage in a cultural exchange that would allow him to express his opposition to the ills of Nationalist politics openly. ${ }^{7}$

\section{Animals and ideological discourse}

The photograph on the cover of Baboondogs, taken by Kramer at the Tygerberg Zoo, is of a baboon's hand with its little finger hooked onto one of the steel bars behind which it is imprisoned. The photograph on the album, released at the height of the liberation struggle in 1986, could be seen to evoke the detention and imprisonment of activists and to compare animal imprisonment and political imprisonment. The lyrics contain many references to animals (lions, mambas, hyenas, locusts, dogs and baboons). Kramer uses these animal

$6 \quad$ Interview by De Villiers and Slabbert at Camps Bay in June 2008.

7 Whereas his previous work often employed satire and parody for social commentary, the lyrics on this album are starkly devoid of humour and mock criticism. In addition, an analysis of the stylistic and thematic content of Baboondogs provides a platform or matrix which aids in unpacking the political views expressed in his previous work. 
references to juxtapose the natural life of wild animals with urban existence; appropriate the stereotypical perceptions about animal features or characteristics as a critique of human behaviour; examine the politically motivated destruction of nature and humans regarded as other; and evoke political chaos and mayhem. In "Mambas in the gutters", the first track on the album, Kramer sings:

There are mambas in the gutters

And the dogs are on the prowl

Hear the hyenas laughing

As the fleeing baboons howl

Can you see the poacher's footprints

As you stare down the barrel of a gun

In a city that has no seasons

I lie like a lizard in the sun

The song further describes the "lions roaring [...] in the city streets" and "a vulture choking in the lounge of a 5 star hotel". Whereas predators and poisonous snakes are used to describe the encroaching power of the oppressor, baboons represent the marginalised and the oppressed. By drawing a parallel between the plight of the baboons and the oppressed races of apartheid South Africa, Kramer moves beyond the use of "animalisation", a process which, according to Ahuja (2009:557) "involves contextual comparisons between animals (as laborers, food, 'pests', or 'wildlife') and the bodies or behaviors of racialized subjects". He clearly references the racist stereotypes prevalent at the time, which Pechey (2006:43) terms the "aboriginality" of baboons in South African discourse, in which "comparison between South Africa's indigenous populations and chacma baboons" is a given.

\subsection{Primate recognition in "Bobbejaan Bobbejaan"}

The representation of the baboon in the song "Bobbejaan Bobbejaan" demonstrates Kramer's successful negotiation of this complex issue of animalisation. He inverts the stereotypical association between baboons and racialised subjects to reveal a shared primate taxonomy, a shared plight of entrapment: an ontological kinship between the narrator and the baboon. The gravity of the lyrical content is movingly conveyed through Kramer's nuanced delivery and the minimalistic accompaniment - the haunting sound of the harmonica and acoustic guitar. The narrative is based on a recollection of a set of childhood memories, stimulated by two photographs which the speaker unexpectedly comes across. The memories are prompted, first, by a "picture of the baboon with my Dad" 
and, second, by "a picture of me and my Mom". In the first instance, the syntactic arrangement is important: "the baboon with my Dad" and not "my Dad with the baboon" anticipates the final moment of recognition with the baboon.

The speaker's initial reaction to each of the images is conveyed in light-hearted colloquial idiom which is meant to amuse ("hey check" and "here's nog a picture"), but it seems forced to minimise the emotional discomfort associated with the recollection and to impress the listener with feigned familiarity and a dramatised retelling ("hey check my old man" and the emphasis on "laughing at first"). The emotions associated with the recollection of events gradually alter: the amused tone of "my old man" in the first verse shifts to carry a tone of contempt in the second verse. The narrator remembers how his father would "make / like he'd let [the baboon] come inside [the car] / laughing at first / but then get cross if I cried". By scaring the boy with the baboon, the father emphasises that the baboon is the frightening other, an act that exposes the animal as a threat to the boy. The child responds with fear to the father's overt performance of a distorted masculinity. He clings to his mother and starts to cry. The father then acts out by imitating the baboon ("scratching at his armpits and howling at the moon"). He makes himself ridiculous and becomes ridiculous in the eyes of his son. His performance does not only undermine his attempts to enforce his masculine identity, but further illustrates his misinterpretation of animal behaviour8 (the baboon that howls like a dog) and his lack of sympathy and insight. The father's ludicrous imitation, therefore, projects his ambiguous position: being neither primate nor canis, he becomes a baboondog. 9 Ironically, the imitation of hybridity neither reveals a position of reconciliation and insight, nor presents a process of "becominganimal", described by Deleuze and Guattari (2004) in Animal philosophy: ethics and identity and defined by Woodward (2008:4) as "a similar ontological process to shamanism which undermines fixed

Baboons do not howl at the moon, they are diurnal and because of their nocturnal vulnerability, they remain stationary at night. Vocal communication is reduced to minimal expressions of discomfort or warning barks. My scrutiny of primatology studies by De Waal (2001), Gerber (2004), Goodhall (1978), Redmond (2008), Taylor and Jackson (2004), and Wright (1994), for example, produced no evidence to confirm that baboons howl at night. On the other hand, sources confirm that animals belonging to the Canidae family, such as the jackal, wolf and dog have been described as nocturnal howlers (Crosby, 1977:21).

9 See Gerber (2004:39-40) and Redmond (2008:10) for further discussions of linguistic use of the terms and references to baboon and dog hybrids. 
identities, as well as crossing thresholds". It instead serves to confirm the father's speciesism 10 which coincides with his racism. Considering the politicised thematic content of the album, the father's attitude reveals him as a white, male authoritarian representative of the broader political milieu of apartheid South Africa.

If one were to read the line "it walked on its fists and wore a collar and a chain" as "[he] wore a collar and a tie", the parallel between human and nonhuman animal could suggest the father's similarly entrapped position, both within a socio-political framework and a gender binary, a role which the boy, as his son, would be expected to imitate. It is this subconscious awareness which motivates the child to shy away or to "hide [his] face" from the animal's gaze and later to emulate the father's cruel behaviour when he consciously sets out "alone" to confront and threaten the baboon in mimicry of his father's conduct (to imitate his behaviour and to vent his anger through abuse).

The chained baboon in the park, ironically referred to as "the pet baboon", like the photograph on the cover of the album, could be seen to evoke what Pechey (2006:44) describes as "colonial anxieties" and "racial and political mythologies" evident in South Africa's colonial and political history. Like the Khoisan11 (or Bushmen), the baboon has been removed or banished from its natural territory, deprived of its right to roam free, colonised, hunted, and concurrently regarded as a threat and as a comic object of entertainment and exhibition. It is telling that both baboons and Bushmen were classified as vermin in the nineteenth and early twentieth centuries. One of the most infamous examples of these acts of exploitation and exhibition of the Khoisan, is the life and ordeals of Saartje Baartman. A perhaps less well-known example is the figure of Koos Sas on which Kramer based his musical Ballade van Koos Sas. Set in the early twentieth century, the musical tells the story of the notorious Sas who is hunted (first for theft and murder and, posthumously, for his skull) by various white characters. However, Kramer does not merely appropriate colonial discourse to compare racialised subjects with baboons. As the final encounter between the boy and the baboon illustrates, the animal's physical entrapment and powerless

10 Hellen Tiffin describes speciesism as "a theoretical problem connected inextricably to racism, sexism and colonialism" (Mason, 2006:120).

11 See De Villiers (2010:59) for my use of the terms Khoisan, San and Bushman. 
position signify the epistemological entrapment of human and nonhuman animals by political and cultural ideologies.

On a late afternoon, the boy "pedals" to the park to confront the baboon. The narrator remembers:

I picked up a stone

$\mathrm{Ja}$, it watched me as I came

sitting on its pole

in the cold winter rain

we stared at each other - just us

two in the park

then I got on my bike and rode

home in the dark

The explanation "just us / two in the park" emphasises their shared loneliness and suggests a certain level of camaraderie. The moment of recognition occurs when the child comes face to face with the animal's gaze. The mutual act of looking becomes what Mason (2008:130) describes as "a mode of engagement with the idea of the other that seeks [...] to move beyond such culturally encoded boundaries as exist between human and nonhuman animals". The recognition tacitly imputes an awareness of evolutionary processes. In the time that elapses between "late afternoon" and "dark[ness]",12 a sense of shared subjectivity is established between boy and baboon while they observe each other. The moment of recognition between the boy and the baboon, the realisation of "common ancestry" (Mason, 2006:131) and the boy's ability to sympathise with the baboon perform what Mason (2006:135) describes as "the way we attend to, and engage with others in the process of imagining, and living in the world" or to "imagine being an other" (Marais, 2006:138). At another level of reading the event, one could argue that it emphasises the artist's feeling of alienation and entrapment within the political South African context at the time. Government

The time of day, the mutual observation, the recognition, and the change of mood created by the remark "I rode home in the dark" recalls Marais' writings on Hesperian (evening) depression in The soul of the ape (Marais, 2002). Marais $(2001: 101,102)$ argues that "normal mental pain" in both humans and baboons "is at its highest flow in the time of the setting sun" and it "reaches a climax immediately after sunset and endures for a short period [...]". He continues by saying that "little children are by no means exempt" from these conditions and that his observation of the chacma baboon's behaviour similarly illustrates a "representation of the same inherent pain of consciousness at the height of its diurnal rhythm" (Marais, 2001:106). 
censorship inhibited freedom of artistic expression and "Bobbejaan Bobbejaan" therefore raises questions around issues of artistry.

The beautiful, yet disturbing chorus, with its description of the baboon's tragic-comic performance functions as a foil to convey artistic reflection:

Bollemakiese bobbejaan
Bobbejaan
Bollemakiese deur die lug
Bollemakiese bobbejaan
Bobbejaan
Die ketting om sy lyf trek
hom terug

What seems like an attempt to entertain (a playful and comic summersault) is brutally inhibited by the restrictive chain, and the movement becomes a distorted and painful retreat back into captivity and submissiveness to emphasise the animal's disempowered position. In the penultimate chorus, Kramer changes the line "die ketting om sy lyf trek / hom terug" (the chain around "his" body tugs him back) to "die ketting om jou lyf trek / jou terug" (the chain around "your" body tugs "you" back) (emphasis - MS). The referents of the second person pronoun in this shift are ambiguous (singular or plural); they do not merely suggest a universal reflexive scrutiny for listeners (or readers) about the possibility of their own mental and corporeal enslavement, but underscore the boy's altered perception of the baboon (and, I would like to argue, vice versa): from his (or their), the other, to your (or our) shared suffering. Keeping in mind the "transgression of species boundary" (Mason, 2006:136) that occurs in the moment of recognition, the pronominal shiftiness in the revised chorus, could be read as the baboon (one primate) communicating to the boy (another primate) his entrapment. This could also be read as the artist's self-reflection on censorship which emerges when the older self looks at the photographs with a more empathetic identification - a point poignantly proven by the fact that some songs on Baboondogs were banned from broadcasting by the authorities.

Whereas the photograph of the father and the baboon stirs unpleasant and painful recollections in the narrator, the photograph of the boy with his mother in her "bright flower dress" brings positive memories of the maternal and feminine, which contrast strongly with the masculinity of the father. It is significant that the boy comes to her to ask about his origin ("where do I come from?") and her 
response ("we caught you in the mountains / and shaved off your hair") conveys two important points. First, in a joke, she relays a version of a traditional myth which many parents told (and still tell) children to avoid what they regarded as embarrassing explanations about sexual intercourse, pregnancy and birth. The mother's myth, which in all likelihood originated in Western societies 13 in a response to Darwin's The origin of species by means of natural selection (1859), indeed holds an instinctive, if transformed, truth about evolutionary primate speciation and underscores the bond between the young boy and the baboon. She places the boy with the baboon ("we caught you"), but this association with the baboon does not contain the same threat as the father's act of frightening the boy and foreshadows the moment of recognition. The father's failed performance is a parody, a failure of masculinity that leads to the boy's loss of empathy with the father in favour of the baboon. Second, the removal of the hair, an indicator of animalness, effects the humanisation of the boy. The boy (baboon) is now integrated into the family. He is not the baboon on the chain. This humanising of the wild, the removal of the hair (an addition to this myth necessitates a chopped tail), nevertheless implies an act of violence performed on the animal and the child. The violence inflicted on the other in domestic space, implies national violence evident in the broader political framework of apartheid South Africa.

\subsubsection{Intertextual references to baboons and dogs in Kramer's narratives}

In many South African folktales, songs and legends, the baboon is often represented in conjunction with the figure of the dog. Kramer uses this convention in his song "Boggom en Voertsek", a retelling that contains intertextual references to both Leipoldt's and Opper-

13 Gerber (2004:58) explains that the myth of becoming a human primate after captivity is reversed in the didactic folktale of the amaMfene tribe. According to legend, people who were too lazy to work the land were banished from society into the wild with their pick-handles tied to their backs, the pick-handles became tails, the humans grew hair and were eventually transformed into baboons. Bushman oral tradition contains similar reference to a reversal of "evolution", although in this case the baboon is respected and regarded as a dangerous, powerful and clever adversary, as illustrated in Dia!kwains conversations with Lloyd: "My parents used to say to me, that the baboons were once people at the time when we who are people were not here" and "although baboons may be like people, they are 'strangers', people who are 'different' [...] the reasons for their differences go back to the time of the Early Race when all the animals lived together, gathering and hunting much as the !Xam did" (Hollmann, 2004:7, 10, 24). 
man's similarly titled poems.14 Gilfillan (1980:41-43) explains that Leipoldt's "slampamperliedjie" (a carousel-song, normally about a loafer, an idler or fellow tippler) was the source for Opperman's embittered and aggressive existential reflection. Opperman's version explores the futility of a lonely and desolate life lived in fruitless search for meaning within the confines of the city space, ultimately pointless but made bearable through the abuse of alcohol and other narcotic substances. However, in Leipoldt's version, as Gilfillan (1980:38) points out, the two characters go through a series of lonely phases together: they lived ("gelewe"), they wandered or travelled ("geswerwe"), they nagged ("gesanik") and they died ("gesterwe"). The phases are metaphorically represented through Boggom's (the baboon) and Voertsek's (the dog) experiences in the Hantam. Kramer's mock ballad elaborates on Leipoldt's version and, like Opperman's, employs parody as poetic medium to execute what Preminger describes as "the double-edged task of reform and ridicule" (Gilfillan, 1980:41).

In Kramer's ballad, the two companions from the Hantam in the Northern Cape (a seemingly barren, desolate landscape) travel to Cape Town in an old Pontiac (sporting Kentucky Fried chicken vests and drinking wine). They are eventually pursued in a heated chase by traffic officers (and here Kramer introduces two more familiar folktale characters, jackal and pig) and subsequently incarcerated for speeding in the jail in Napier. The corrosive effects of a corrupt consumer society and the moral decline of those who fall under its spell, are evoked in the repeated nostalgic references to the untarnished landscape they travel through and finally leave behind. In Leipoldt's ending the two characters die together, but in Kramer's version the demise of Voertsek is dismissively referred to in the last line of the lyric ("ou Voertsek ...? Ag hy's lankal vrek" [old Voertsek is long since dead]) and Boggom remains alive. By keeping Boggom (a branded criminal) alive as a member of the local town council, Kramer's social commentary relies on the marginalised baboon that becomes a figure of authority. Although the characters are anthropomorphosised, the use of the expression vrek is significant as Landsman (1997:191) explains in her novel The devil's chimney: "There's no word for vrek in the English language, animals vrek and people die in Afrikaans but in English everything just dies." To say a human "het gevrek" in Afrikaans is to express contempt and disgust

14 Kramer confirms in numerous interviews that his work has been influenced by authors such as Leipoldt, Opperman, Bosman, De Vries and Gordimer. 
toward such a person and to animalise the person or the manner of death. The critique of white Afrikaner culture is deftly disguised in the fact that Voertsek is the only character in the tale awarded a surname - Van der Merwe - a name which is traditionally used as a satirical and symbolic typification of white Afrikaner ignorance and inanity. Furthermore, the name Voertsek is an abusive Afrikaans term, used to drive away an unwanted dog. The word has since infiltrated the vocabulary of most South Africans, regardless of their mother tongue, to be used as an insult aimed at another human.

\subsection{The figure of the dog}

Much has been written about the representation of the dog in global literature, but it was with the publication of Coetzee's award-winning novel Disgrace (2000) that it became an important topic in South African literary scholarship. However, most critics focused on the symbolic value of dogs in Coetzee's text, whereas scholars like Tiffen and Mason (Mason, 2006:131), who work in animal and postcolonial studies, point out that

[d]ogs in [...] Disgrace act in symbolic and literal ways to initiate a shift in certain characters ideologies that make transgressing the species boundary ideologically and imaginatively possible (emphasis - MS).

Lurie's daughter Lucy expresses just this view when she says to her father:

[...] there is no higher life. This is the only life there is. Which we share with animals. [...] I don't want to come back in another existence as a dog or a pig and have to live as dogs of pigs live under us (Coetzee, 2000:74).

Woodward, one of the first to publish a book on animal subjectivities in South African literature, also addresses the difference between human-dog or human-domesticated animal relationships. She points out that, because dogs are allowed into "family" space, "the relationships between dogs and humans are more familiar" (Woodward, 2008:91). Woodward further explains that human perceptions about dogs and interactions with them are culturally and class dependant, as "discussion on dogs in [various disciplinary and ideological] discourses" illustrate (Woodward, 2008:93). Whether the dog is regarded as property, a companion, a family member - as Stiegler argues (Barison \& Ross, 2005: audiovisual) - or an equal, depends on cultural and class perspectives. 
In Kramer's oeuvre the dog shadows him like a faithful companion on his lyrical journey through the transformed cultural landscape of South Africa. His metaphorical and allegorical use of the dog evokes a range of emotions such as feelings of entrapment, alienation, loneliness and marginalisation.15 In "Bleskop" the speaker is alone at home and his longing for the absent beloved is portrayed in a series of comparisons, one of which is that he feels like a dog without hair ("nes 'n hond sonner hare"). In the song "Katie", however, the dog becomes a symbol for desire and infidelity ("'n rondloophond loop heel nag rond"). "Hekke van Paradise", "Dikwiel bicycle" and "Botteltjie blou" contain images of white suburbia with dogs trapped behind gates and walls, their persistent barking evoking feelings of rejection and exclusion in the speaker. These images also subtly hint at suburban racist anxieties about "die swart gevaar" ("hoekom blaf daai honne by die hekke van Paradise?"; "[ek] ry my fiets op en af verby die hond wat blaf" and "net waar ek loop skree hulle voertsek"). Implicit in these descriptions are moments of existential reflection and/or a culturally encoded sense of identity, as is evident in "Die pad", where the speaker adopts society's description of him and names himself a dog ("ek skrik vir niks ek is Willem hond"). Although Kramer continues to use dogs in his lyrics, reference to animals in his more recent work, indicates a shift from political to ecological awareness.

\subsection{Nature and ecological consciousness in Kramer's lyrics}

Kramer's album Hemel \& aarde (2007) is arguably the first "green" Afrikaans album to carry an explicit human-nature interdependency message. Using Deleuze and Guattari's notion of "becoming-animal", I here argue that Kramer's lyrics urge a process of "becomingnature", which aims to erase the human and nature divides evident in athropocentric and biocentric approaches to ecology. Songs such as "Die ou aarde" (This old earth) express a poignant critique of over-population and the threat of global environmental destruction. This song both celebrates the planet's brave efforts to endure and warns against "her" indiscriminate hospitality ("sy sê welkom / jammer maa' die rit is so kort").16 Despite his musings on the destruc-

15 The scope of this article does not allow a detailed exploration of the role of the dog in Kramer's work, but I broadly summarise through illustration. See tracks on Bakgat! (1980), Klassic Kramer (1996), Huistoe (2004) and Hemel \& aarde (2007) for the examples cited in this section. maternal body ("haar lyfie bloei terwyl die mensdom groei"). He also describes 
tiveness, cruelty and stupidity of human action in songs such as "Hoekom?" (Why?) ("hoekom issie mensdom so dom? / gee vir hom a paradys / dan pluk hy elke blom"; "gee vir hom twee hanne / en dan bou hy hom 'n bom"), Kramer's view of the earth's capacity to survive is essentially optimistic. For him a balanced, mutually respectful and sustainable relationship between humans and nature is indeed possible, if the spiritual interconnectedness of all life forms is honoured.

In "Maak jou oë oop" (Open your eyes), the likeness between humans and nature is depicted through the metaphor of an exclusive fingerprint, described as a masterpiece ("meesterstuk"), where the lines or puzzles on a human hand ("daars 'n legkaart in the palms van jou hande") resemble each unique leaf on the branches of a tree ("Baie takke en op 'aai takke baie blare / nes 'n vingerafdruk"). He argues that earth's flora and geological formations literally speak a language, if only we would listen:

In my wêreld is daar plekke wat kan praat

'n kloof, 'n koppie, die hoek van 'n straat

Klippe sing innie grond

Hulle maak gesond

Al lyk hulle vir jou so stom and bont (I. 18-23)

In my world there are places that can speak

a kloof, a koppie, the corner of a street

stones sing in the soil

they heal

though to you they seem mute and variegated

Celebrations of the interconnectedness between humans and the cosmos are prevalent in many philosophical and spiritual traditions, for example in Buddhism and in the belief systems of panentheism. According to Müller (2008), panentheism can be distinguished from pantheism, which posits that God (theos) is in everything (pan), whereas panentheism paradoxically posits that every part of the cosmos exists within God and God pervades and interpenetrates every part of the cosmos, yet remains transcendental. Müller argues that Hemel \& aarde carries such a panentheistic message, as defined by the philosopher Krause in the late sixteenth century.

the earth as older than the Bible and older than the word. The reference to the Bible can be seen as an implicit critique of a dogmatic belief system which enforces a hierarchical distinction between human and non-human animals, a view that contributed significantly to the exploitation and destruction of nature. 
Kramer's song "Die duiwel" (The devil) appears to subscribe to such a philosophy.

Moet jou nie misgis 'ie

Vannie vlees offie vissie

Elke ding het 'n stukkie god

En daai vlam kan jy nie blussie (I. 41-45)

Don't be mistaken

about the flesh or the fish

everything has a bit of god

and you can't extinguish that flame

Aspects of panentheism can be linked to the belief systems and shamanic practices of the Khoisan, which Kramer repeatedly refers to in his oeuvre. The broader views contained in animism, "the belief that all things in nature, such as plants and hills, have a soul" (Soanes \& Hawker, 2006:33), are also applicable here.

Although Kramer's ecological concerns expressed on Hemel \& aarde often encompass a cosmological perspective, his illustrations mostly remain located in the topology of the Cape, Karoo and Northern Cape. In "Die duiwel" his sense of connectedness with the vastness of the Karoo landscape and the darkness of the night sky ("donker Karoo") stirs a realisation of the unity suggested in panentheism. Despite the speaker's feelings of loneliness in an isolated and dark space, he remains acutely aware of his interconnectedness with the universe and divinity. God is not seen as a figure of authority elevated above humankind. Instead, the Karoo night sky inspires awareness that godliness and "beastliness" reside equally in all. The speaker says he knows the devil, but also observes,

Niemand wil my glo nie

Die hemel hettie vloer nie

God sit nie op 'n troon nie

Die hemel issie so nie (I. 5-8)

nobody wants to believe me

heaven has no floor

God does not sit on a throne

heaven is not like that

Kramer's association with the Karoo and his commentary on the evolutionary and ecological significance of the region are best illustrated in "Onnerwater" ("Under water") on Huistoe (Kramer, 2004). The song prompts reflections on the geographical, archaeological and anthropological importance of the area: 
ken jy die karoo

hier bly slang en akkedis

baie jare terug

was daai akkedisse vis

nou kry jy skulpe innie rotse

jy kry skedels innie klei

hierie hele droë leegte

onnerwater, glo vir my (l. 1-8)

do you know the Karoo

where snakes and lizards live

many years ago

those lizards were fish

now you find shells in the rocks

you find skulls in the clay

this whole dry emptiness

under water, believe me

The lyric traces the evolutionary development from fish to reptile, and by implication from fish to human, as inscribed on and embodied in the geological formations, fossils and rock art of the land. Kramer continues by referring to human-nature interconnectedness as depicted in the rock paintings of the indigenous people who inhabited this dry landscape before colonialism. He encourages the listeners to:

ga' loop 'aa innie klowe daa' onnerkant die krans kry jy olifant renoster en oumense wat dans handjies teen die rotse musiekmaak virrie maan kolletjies en merke wat niemand kan verstaan (I. 32-39)

go walk through the ravines there beneath the cliff you'll find elephant rhino and old people who dance small hands on the rocks making music to the moon small dots and markings that no one can understand

The imagery evokes the mythic, and represents the practices of people such as the Bushmen and Quena ("sien jy die klein kliphuis / dissie oumens quena kerk") who celebrated their close relationship 
with nature through incantation, performance and art. Once an ocean now a desert, the region as a microcosm of the broader South African landscape has been systematically contained, plundered and abused by those who colonised it. The song implicitly critiques the religious practices introduced by the missionaries, which undermined nature-human interconnectivity through the words "dink hul ry die hemeltrein / ma die duiwel stookie vuur" (they think they ride the train to heaven / but the devil is the stoker).

Kramer similarly uses the landscape of the Northern Cape to posit questions about human-nature interdependency, environmental exploitation and the effects thereof on the people who inhabit these regions. "Die verlosser" (The saviour) on Hemel \& aarde is his sinister and uncanny retelling of "The pied piper of Hamelin". In this lyric he also skilfully investigates elements of the rainmaker myths of Bushman mythology, in which rain (and bitter-sweet prosperity) is called unto the land through the mysterious rainmaker's shamanic trance dances and lively music-making. The figure of the rainmaker in the song merges a narrative from Western culture with various traditional practices in South African culture. A mysterious stranger, carrying a guitar and a suitcase, arrives in a drought-stricken village ("ses lang jare het dit nie gereën nie / die staalblou hemel het ons nooit geseën nie / die bokke ennie skape het gevrek"). The man promises to bring rain, but desires the most beautiful girl in the town as reward should he succeed. For days the stranger makes music and performs trancelike dances with his own shadow. At last the ritual proves successful, but the town's people fail to deliver their side of the bargain; they instead attempt to bribe the rainmaker with meat and alcohol ("ons braai vir hom worsies / ons skink vir hom dop"). He finally departs, and, the following morning, the villagers awake to discover that all the town's children have disappeared. Despite the fact that it then rains regularly and the region flourishes ("ons het ryk geword / die veld het geblom"), life in this village remains dismal and depressing (nobody laughs, food is tasteless and communication virtually ceases). The song warns against the abuse of sacred and divine powers, which emphasises the interconnectedness between ecosystems and communities.

"Dans mettie dood" (Dance with death) on Huistoe also deals with human-nature interdependency. It explores the effects of contemporary commercial practices, for example tourism (its benefits and side-effects) on landscapes such as Namaqualand and the Richtersveld. The song furthermore posits questions about environmental injustice when the fragile living conditions of the inhabitants in these 
regions are considered from a historic and current political perspective. Kramer refers to those who brought bibles ("hulle kom met die swart bybel"), alcohol ("met die brannewyn en bier") and guns ("hie ko mense met gewere") (I. 20-25) to subjugate, banish and destroy (and consume) the abundance of wildlife. The song also suggests that the process of exploitation evident in the country's colonial past (perpetuated in the construction of apartheid South Africa) continues in socio-economic structures where previously marginalised groups remain in disenfranchised positions:17

Hier't 'n man gekom vannie gowwernment In sy slangvel skoene loop hy penorent Hy belowe ons die baksteen en sement Niemand glo meer daai ou storie Ons het nooit weer van hom gehoor 'ie Hy bly innie stad ma wie betaal sy rent? (I. 16-21)

a man came here from the government in his snake skin shoes he walked erect he promised us bricks and cement nobody believes that story anymore we never heard from him again

he lives in the city but who pays his rent?

People living in these regions rely greatly on the income generated by the annual influx of tourists who come to view the blooming spring flowers. Both nature and humans depend on rainfall for prosperity. The misery of living in a semi-desert area is evident in the speaker's lament,

ek staan heel maand en wag virrie reën se reuk want sonner water sallie veld'ie blommie sonner blomme sallie geld'ie kommie sonner geld wil amal vir almal neuk

17 In "Matchbox full of diamonds" on Eina (Kramer, 1989) Kramer tells the story of a man who works on the diamond mines in the Richtersveld. It is implied that the narrator, who is walking "on the road to Lekkersing", has stolen diamonds, which are hidden in a match box. The joy of putting an end to his poverty is symbolised in "I am as happy as a hotel / in the springtime / when the flowers bloom again". The Northern Cape - Richtersveld and surrounding areas contains particularly significant examples of the socio-economic imbalance and environmental injustice evident in South African society. In places such as the diamond fields of the Northern Cape and limestone mines at Vioolsdrift, for example, the people who work on these mines endure dismal living conditions and face serious health risks; issues which have been largely ignored and remain unaddressed by national and regional government. 
I have been waiting the entire month for the rain to come, without rain the flowers will not bloom, without flowers there will be no income, without an income everyone wants to hit one another.

Kramer further comments on pollution, destruction of vegetation by vehicles, the B\&B industry and commodity fetishism ("kameras"). This eco-tainment, to appropriate Louw's (2006:146) term for the "elements of spectacle" where nature and animals become commercial objects exploited for human entertainment, appears not to be sustainable. It leaves nature in a permanently altered state as the speaker nostalgically summarises: "almal is op soek na die ou Karoo / as jy daai wil sien kyk net in my oë / die wêreld verander voor jy jou oë uitvee" (everyone is in search of the old Karoo, if you want to see it just look into my eyes, the world alters before you wipe your eyes).

\section{Conclusion}

South Africa is not alone in facing this process of environmental exploitation of both humans and nature, but is part of a global condition, as American critic Kilcup (2009) points out in her discussion of the pitfalls in teaching literary environmental criticism. She calls it

... a throwaway culture in which companies externalize environmental costs with tacit or explicit governmental support, a capitalist system that prioritizes economic gain and promotes environmental injustice, and a culture of individualism that fractures relationships and prevents structural change (Kilcup, 2009:848).

As is the case internationally, ecocriticism and animal studies are still in their developmental phases in South Africa, and both fields have at times met with academic sniggering (researchers are often labelled as green neo-colonialists, "bunny- and tree-huggers", etc.). Perhaps a more useful position is that of Wylie (2007:256), who, whilst expressing his discomfort "with the term ecocriticism" because "it implies a cohesive school of thought", nevertheless argues that:

In the South African context, this may be a good thing; it may allow for flexibility in methodology which could accommodate dramatic cultural differences while eluding the charge of being just another imperialistic or neo-colonial imposition. There is little point ignoring the fact that 'ecocriticism' is an import ineluctably tied to the literary, if not indeed to the academy, and therefore implicitly to the politics and ideologies of industrial 
capital - even as it often asserts itself as a vehicle of challenge to those very hegemonies.

Lemmer (2007:223) begins her introduction to the special issue on ecocriticism of the Journal of literary studies with Slovic's question: "Could it be that the most important function of literature today is to redirect human consciousness to a full consideration of its place in a threatened natural world?" In this article, it has been my contention that Kramer's work illustrates Slovic's point that we have to live our awareness and feel our presence in the world, and that "we need literature - or art more generally - to help us use our senses more fully and intensely" to "enter the realm of sensory ecology" (Slovic, 2008:137). Kramer's music and his steadfast dedication to celebrate the rich cultural heritage of a heterogeneous South Africa should not be overlooked in the important process of "learn[ing] how to speak / With the voices of the land" (Cronin, 1989:235).

\section{List of references}

AHUJA, N. 2009. Postcolonial critique in a multispecies world. PMLA, 124(2):556-563.

BARISON, D. \& ROSS, D. 2005. The ister: based on Martin Heidegger's 1924 Hölderlin lectures. Black Box Sound \& Image.

COETZEE, J.M. 2000. Disgrace. London: Vintage Books.

CRONIN, J. 1989. To learn how to speak. (In Chapman, M. \& Voss, T., eds. Accents: an anthology of poetry from the English-speaking world. Johannesburg: Ad Donker. p. 235.)

CROSBY, M., ed. 1977. World encyclopedia of dogs. Hong Kong: Octopus.

CURRY, P. 2008. Nature post-nature. New formations, 26(Spring):51-64.

DE VILLIERS, D. 2010. Van daai plek: David Kramer, Die Ballade van Koos Sas, and the ground of being. Journal for literary studies, 26(2):58-68.

DE VILLIERS, D. \& SLABBERT, M. 2011. David Kramer: a biography. Cape Town: Tafelberg.

DE WAAL, F.B.M. 2001. Tree of origin. Cambridge: Harvard Press.

DELEUZE, G. \& GUATTARI, F. 2004. Becoming-animal. (In Calarco, M. \& Atterton, P., eds. Animal philosophy: ethics and identity. London: Continuum. p. 87-100.)

GERBER, A. 2004. Bôgom. Epping: LAPA Uitgewers.

GILFILLAN, F.R. 1980. Maanlig en rose. (In Scholtz, M., ed. Leipoldt 100. Kaapstad: Tafelberg. p. 34-43.)

GOODHALL, J. 1978. In the shadow of man. 2nd ed. London: Collins English Library.

HOLLMANN, J.C., ed. 2004. Customs and beliefs of the /Xam Bushmen. Johannesburg: Wits University Press.

KILCUP, K.L. 2009. Fresh leaves: practising environmental criticism. PMLA, 124 (3):847-855.

KRAMER, D. 1980. Bakgat!. Blik Music.

KRAMER, D. 1986. Baboondogs. Blik Music.

KRAMER, D. 1989. Eina. Blik Music. 
KRAMER, D. 1996. Klassic Kramer. Blik Music.

KRAMER, D. 2001; 2008. Die ballade van Koos Sas (stage production).

KRAMER, D. 2004. Huistoe. Blik Music.

KRAMER, D. 2007. Hemel \& aarde. Blik Music.

LANDSMAN, A. 1997. The devil's chimney. London: Penguin.

LEMMER, E. 2007. Introduction: special issue ecocriticism. Part 1. Journal of literary studies, 23(3):223-227.

LOUW, P. 2006. Nature documentaries: eco-tainment? The case of MM\&M (Mad Mike and Mark), 18(1):146-162.

MARAIS, E.N. 2002. The soul of the ape. Somerset West: Phillips.

MARX, L. 2008. The idea of nature in America. Deadalus, 137(2):8-21.

MASON, T.V. 2006. Dog gambit: shifting the species boundary in J.M. Coetzee's recent fiction. Mosaic: a journal for the interdisciplinary study of literature, 39(4):129-142.

MÜLLER, J. 2008. Hemel sonder vloer, God sonder troon. Rapport. http:ww.news24.com/Rapport//Perspektief0,,752-810_2307701,00.html Date of access: 4 Feb. 2008.

PECHEY, L.C. 2006. Problem animals, indigeneity and land: the Chacma baboon in South African writing. Current writing, 18(1):42-61.

REDMOND, I. \& GOODHALL, J. 2008. The primate family tree: the amazing diversity of our closest relatives. Cape Town: Struik.

ROUP, J. 2004. Boerejood. Auckland Park: Jacana.

ROUSSEAU, L. 2000. Eugène Marais and the Darwin syndrome: die dowwe spoor van Eugène Marais. Pretoria: Protea Boekhuis.

SLOVIC, S. 2008. Going away to think: engagement, retreat, and ecocritical responsibility. Reno: University of Navada Press.

SOANES, C. \& HAWKER, S., eds. 2006. Oxford English Dictionary for students. Oxford: Oxford University Press.

TAYLOR, B. \& JACKSON, T. 2004. Apes and monkeys. London: Southwater.

WOODWARD, W. 2008. The animal gaze: animal subjectivities in Southern African narratives. Johannesburg: Wits University Press.

WRIGHT, R. 1994. The moral animal: evolutionary psychology and everyday life. London: Abacus.

WYLIE, D. 2007. Kabbo's challenge: transculturation and the question of a South African ecocriticism. Journal of literary studies, 23(3):252-270.

\section{Key concepts:}

animal studies

ecocriticism

ecological consciousness

Kramer, David

Kernbegrippe:

dierestudies

ekokritiek

ekologiese bewustheid

Kramer, David 